\title{
Does Intellectual Monopoly Help Innovation? ${ }^{1}$
}

\author{
Michele Boldrin and David K. Levine
}

First version: November 8, 2009

This version: December 25, 2009

\section{Introduction}

We are witnesses to both an intense debate over copyrights and patents and a general agreement that some special kind of legal protection is needed to secure for inventors and creators the fruits of their labor. For all the emotion, it seems both those in favor of strengthening and weakening existing protection agree that intellectual property laws need to strike a balance between providing sufficient incentive for creation and the freedom to make use of existing ideas. Put it differently, both sides agree that intellectual property rights are a "necessary evil" that fosters innovation, and disagreement is over where the line should be drawn. For the supporters of intellectual property, current monopoly profits are barely enough; for its enemies currently monopoly profits are too high. In fact, one is tempted to say, for many "enemies" of intellectual property, profits are always too high as long as they are positive.

In our recent book Against Intellectual Monopoly we reach conclusions that are at variance with both sides. We are not of the view that innovators should work out of benevolence. Certainly few people do something in exchange for nothing. Creators of new goods are not different from producers of old ones: they want to be compensated for their effort. However, it is a long and dangerous jump from the assertion that innovators deserve compensation for

\footnotetext{
${ }^{1}$ Based on our book Against Intellectual Monopoly and on the papers presented and the discussions that took place at the WUStL Law School Conference, in April 2009.
} 
their efforts to the conclusion that patents and copyrights, that is monopoly, are a good way of providing that reward. Since innovators may be rewarded even without patents and copyright, we should ask: is it true that intellectual property achieves the intended purpose of creating incentives for innovation and creation that offset its considerable harm?

There are three broad types of intellectual property recognized in most legal systems: patents, copyrights and trademarks. Trademarks are different in nature than patents and copyrights: they serve to identify the providers of goods, services or ideas. Copying or imitating - which would be violations of either copyright or patents - are quite different from lying - which would be a violation of trademark. We do not know of a good reason for allowing market participants to steal identities or masquerade as people they are not. Conversely, there are strong economic advantages in allowing market participants to voluntarily identify themselves. While we may wonder if it is necessary to allow the Intel Corporation a monopoly over the use of the word "inside," in general there is little economic dispute over the merits of trademarks. We focus, therefore, on patents and copyrights and to these two set of legally protected rights we refer when we use the terms "Intellectual Property" and "Intellectual Monopoly".

Some critics, both at this conference and elsewhere, have argued that the term "monopoly" in this case is too strong. Charles McManus, for example, argues in his contribution to this volume that the term is too strong when applied to copyright because the latter seeks to protect "expression" of ideas, not the idea being expressed. Maybe it is too strong, but, in the English vocabulary, we cannot find a better term describing a legal right that allows sellers of, say, books to determine what lawful buyers of their product are allowed to do with it. In particular, how else to define the following facts, if not as an exercise of a monopoly power? Publishers of academic journals can prevent the original authors of the articles published in the journal from circulating copies of the same, even for free. Citations from books, or music, or movies that were legally purchased cannot be longer than a few lines or seconds without additional payments to the original publisher, even if such citations are obtained through legal and widely available technologies. As a third, dramatic, example consider the recent Google Books or Google Prints disaster, in which publishers of books that had been legally purchased, at library rates, by libraries around the world have successfully challenged the right of such libraries to enter into cooperation with Google in order to 
digitize those books and make them searchable and usable on line, for free, through Google's proprietary technology. Should we not call this an exercise of "monopoly power"? Very well, what should we call it, then? Maybe a crime against culture and the world diffusion of knowledge?

Matter of fact a "monopoly" is, in economic parlance, the exclusive right to sell/produce a certain object of service. The U.S. Constitution allows Congress "To promote the progress of science and useful arts, by securing for limited times to authors and inventors the exclusive right to their respective writings and discoveries."2 Our perspective on patents and copyright is a similar one: From a social point of view, and in the view of the founding fathers, the purpose of patents and copyrights is not to enrich the few at the expense of the many. Nobody doubts that J. K. Rowling and Bill Gates have been greatly enriched by their intellectual property - nor is it surprising that they would argue in favor of it. But common sense and the U.S. Constitution say that these rights must be justified by bringing benefits to all of us.

The U.S. Constitution is explicit that what is to be given to authors and inventors is an exclusive right - a monopoly. Implicit is the idea that giving this monopoly serves to promote the progress of science and useful arts. The U.S. Constitution was written in 1787 . At that time, the idea of copyright and patent was relatively new, the products to which they applied few, and their terms short. In light of the experience of the subsequent 219 years we might ask: is it true that legal grants of monopoly serve to promote the progress of science and the useful arts?

Common sense suggests that it could. How is a musician to make a living if the moment she performs her music, everyone else can copy and give it away for free? Why would the large corporations pay the small inventor when they can simply take his idea? Is not the explosion of creativity and invention unleashed since the writing of the U.S. Constitution a testimony to the powerful benefit of intellectual property? Would not the world without patent and copyright be a sad cold world, empty of new music and of marvelous new inventions? These are the very practical questions our work tries to address.

We begin by asking: why should creators have the right to control how purchasers make use of an idea or new good? This

2 U.S. Constitution Article 1, Section 8. The U.S. Constitution, not being copyrighted, is online at various places, such as http://www.law.cornell.edu/constitution. 
gives creators a monopoly over the idea. We refer to this right as "intellectual monopoly," to emphasize that it is this monopoly over all copies of an idea that is controversial, not the right to buy and sell copies. The government does not ordinarily enforce monopolies for producers of other goods. This is because it is widely recognized that monopoly creates many social costs. Intellectual monopoly is no different in this respect. The question we address is whether it also creates social benefits commensurate with these social costs.

This may also be the appropriate point to discuss Mark Lemley's criticism, according to which "monopolistic competition" is the rule of the game in almost every industry, hence what difference does a patent or a copyright make? It makes a big difference: in the market for shoes or bread competing firms freely select where to position themselves. If one likes to position very close or very far from its competitors, there is no legal constraint to prevent such a choice from being implemented. When patents and copyrights enter the scene the situation change: one cannot choose to compete with our publisher by lawfully purchasing a copy of our book, reproduce it with legal means and try to sell it on the market. The world of free monopolistic competition is an always changing one. The world of legal monopoly is not, for two decades in the case of patents and for pretty much ever in the case of copyrights. Thereby the qualitative difference. Is it also quantitatively important? We believe it is, and the whole book is practically dedicated to show by means of data and facts that Intellectual Monopoly does make a, negative, quantitative difference on our collective wellbeing. We may have made the wrong calculations and we may have looked at the wrong facts, but we need to be proved wrong with facts and data. Just arguing that "cosi' fan tutte" is not enough.

Recognize, first, that intellectual monopoly is a doubleedged sword. The existence of monopolies increases the cost of creation. In one extreme case, a movie that cost $\$ 218$ to make had to pay $\$ 400,000$ for the music rights. ${ }^{3}$ In Against Intellectual Monopoly we go through numerous examples of cases where far from increasing innovation and creation, intellectual monopoly has instead served to inhibit or prevent it. A brief list of examples is instructive:

\footnotetext{
3 The $\$ 218$ movie was Tarnation and the information from BBC News, is at http://news.bbc.co.uk/2/hi/entertainment/3720455.stm.
} 
- Boulton and Watt's steam engine patent most likely delayed the industrial revolution by a couple of decades.

- Selten's automobile patent set back automobile innovation in the United States by roughly the same amount of time.

- The Wright Brothers airplane patent forced innovative work on airplane technology out of the United States to France.

a The patent system of England and France forced the chemical industry to move to Germany and Switzerland, where chemical patents did not exist or were much weaker.

a When Verdi gained copyright over his works he stopped producing new works. More generally, there is no evidence that the adoption of copyrights stimulated the creation of classical music.

Given that we quoted the paradigmatic case of Boulton and Watt, this may be a good place to address the criticisms that George Selgin and John Turner have raised in a couple of occasions against our interpretation of this specific story. We should establish, first of all, that while some of the detailed facts they correct us about are certainly the way they say, an equal number of other are not. So, for example, Ed and William Bull were father and son, and the latter continued the enterprise where the first had left it. Similarly, Hornblower may or may not have paid back huge amounts of royalties to $\mathrm{B} \& \mathrm{~W}$ and may or may not have been a poor businessman, but there is no doubt that $\mathrm{B} \& \mathrm{~W}$ actively used the legal system to prevent him from marketing his own machine. The book also reports the correct statistics for horsepower and engines installed, and we are grateful to Selgin and Turner for pointing us to the more recent and more reliable data, which we used and that yields the very same result. All these details, at the end, do not change the two main facts upon which our argument is founded: B\&W's patent allowed for a monopolization of the English market for steam engines until 1800; the adoption of steam engines exploded only after the patent expired, did so extremely rapidly and it was accompanied by enormous efficiency gains that had been altogether absent during the previous 25 years. We do not make any claim of originality here, dozens of economic historians have argued one of these points or all of them during the last few decades. Our contribution was, purely, to put them together and point the finger to the likely culprit: B\&W's patent. Where Selgin and Turner differ from us, at the end, is on the interpretation of these facts. They see this as a natural development and claim that the trajectory is exponential as 
it should be, in their view. We see it differently and have argued why in the book and elsewhere. This does not seem the place to dwell back on the same set of issues.

Those listed earlier are not the only examples of patent-blocked innovations and development, but are some of the most egregious. In the opposite direction, our book reports numerous examples of how innovation thrives without patents and copyright, and of the various inimical effects of the monopoly wrought by intellectual property. More importantly, we search the empirical literature long and hard without finding a single case in which a strengthening of intellectual monopoly un-controversially increased innovations. We find that a strengthening of intellectual monopoly increases patenting and copyright claims, but patents and copyright do not increase actual innovation.

We are by no means the first economists to reach this conclusion. After reviewing an earlier set of facts in 1958, the distinguished economist Fritz Machlup wrote

"it would be irresponsible, on the basis of our present knowledge of its economic consequences, to recommend instituting [a patent system]." 4

\section{Does Intellectual Monopoly Increase Innovation? Theory}

From a theoretical point of view, intellectual monopoly may both increase and decrease innovation: it provides more revenues to those that innovate, but also makes innovation more costly. Innovations generally build on existing innovations. While each individual innovator may earn more if he has an intellectual monopoly, he also faces a higher cost: he must pay off all those other monopolists owning rights to existing innovations.

A number of economic historians, Douglass North and his followers foremost among them, have argued that the great acceleration in innovation and productivity we associate with the Industrial Revolution was caused by the development of ways to protect the right of inventors, allowing them to profit from their innovations. ${ }^{5}$ Central among such ways was the attribution of

\footnotetext{
${ }^{4}$ Machlup [1958], p. 80. He nevertheless concluded that we should keep the patent system. We discuss his position further in our conclusion.

5 A starting point for Douglass North's views of the role that well defined property rights, and patents in particular, played in the Industrial Revolution are his works of 1981, and 1991. It should be noted that North does not subscribe to
} 
patents to inventors, and their upholding either by Parliament or by the courts. Relative to the very poorly defined contractual rights of pre-seventeen century Europe, plagued by royal and aristocratic abuses of property and contracts, there is no doubt that allowing individuals a temporary but well defined monopoly over the fruits of their inventive effort was a major step forward. Even monopolistic property is much better than a system that allows arbitrary seizure by the rich and powerful. This does not, however, contradict our claim that widespread and ever growing monopolistic rights are not as socially beneficial as well defined competitive property rights.

To put it differently, about four centuries ago, as Western societies moved away from post-medieval absolutist regimes, the establishment of patents constituted a step forward for the creation of a system of property rights that favored entrepreneurship and free market interaction. By the force of the same reasoning, the abolition of patents and of the distortionary monopolistic rights they entail may well result, now, in an analogous boost to entrepreneurial effort and free competition. The contribution that the Neo-Institutional approach may still provide to this debate was well discussed in the paper by Vertinsky, also in this volumen, which raises a number of relevant issues we unfortunately cannot address here. We would like, though, to point out one thing: patents are by no means the only legal instruments allowing for contractability of ideas and for the creation of a maket for technology transfers. Beginning with the pathebreaking work of Jack Hirshleifer in the early 1970s, it has become clear that economically valuable information can be traded in the absence of patents and under condition of competition or nearly so. There is no prima facie evidence, either theoretical or empirical, for the claim that the disappearance of patents would increase transaction costs associated to technology transfer. Most likely, it will reduce them insofar as it will reduce incentives for rent-seeking, defensive patenting, submarine patenting and all the gigantic legal costs these practices have brought upon us. In summary, well defined and protected private property of own ideas does not require monopoly

a naïve view of the evolution of property rights according to which they become progressively more "efficient" or just simply "better" as time goes on and the economy develops. Being aware of the fact they are, more often than not, determined by rent-seeking agents within a political game, North is careful at pointing out that the system of property rights one often faces is substantially inefficient or inefficiency-inducing along more than one dimension. 
over them pretty much in the same way that private property of our own cars does not require the two of us becoming the only motorized citizens of the USA.

Theory also suggests that small countries with low IP protection should witness a surge in the inflow of IP-related investment after their IP protection is increased, as they capture investments from other countries where intellectual monopoly is protected less. The latter is a particular kind of "zero-sum game" 6 that, unfortunately, appears to have gone beyond a mere theoretical possibility. What is less obvious, is what the outcome will be once every country adopts the same high degree of IP protection. Leave aside the more or less terrifying scenarios of escalation - in which countries out-do each other trying to allure IP-related investments by progressively increasing their local protection of intellectual monopoly. It is still worth asking if a world where everyone has the same degree of IP protection as, say, the US currently does is a world with a higher or lower rate of innovation and a higher or lower social welfare than a world with much less IP protection. ${ }^{7}$

\section{Does Intellectual Monopoly Increase Innovation? Facts}

Theory gives an ambiguous answer, so let us look at evidence, supported by a bit of statistical common sense.

Given the continued extension of patent protection to new areas - business practices and computer software, for example -

\footnotetext{
${ }^{6}$ In fact, negative-sum insofar as it increases lobbying efforts and related wasteful transaction costs.

${ }^{7}$ Writing about the use of patents to lure investments away from other countries tempted us to engage in a digression on the role that patents played in Europe, roughly, between 1400 and 1800 . Here are some hints for further reading. The original purpose of patents was to attract specific groups of artisans and highly skilled professionals that were, for a reason or another, lacking in the country or city promising the patent. Monopoly was the carrot offered by most Italian and Northern European cities to inventors that agreed to emigrate and set up shop there. In England, during the seventeenth, eighteenth and most of the nineteenth centuries a royal patent privilege was awarded to those citizens who would travel abroad and be the first to bring back new goods and technologies. United States patent laws were less inclined to provide incentives to pirate foreign innovators, but it still discriminated heavily against foreign citizens and innovations until the 1861 reform; pirating of foreign inventions, especially British, was thriving. Notice the interesting fact: all these practices just amounted to imitation, or piracy in modern jargon, rewarded with local monopoly! This is something worth keeping in mind in the light of current sermons against Indian, Chinese, Mexican and Brazilian people "pirating our inventions." Our reading of historical records is that all this "reciprocal stealing" had no effect on the total amount of inventions.
} 
one might hope that there is recent strong evidence that the introduction of patent protection has lead to a substantial increase in innovation. These hopes, alas, are not to be fulfilled: It is already apparent that the recent explosion of patents in the U.S., the E.U. and Japan, has not brought about anything comparable in terms of useful innovations and aggregate productivity. This we asserted a few years ago, while writing the book, and it is readily apparent today, in the midst of the Great Recession: the patents' explosion, certainly, did not bring about any increase in aggregate productivity.

While there is no hope of finding evidence supporting the claim "more patents $=$ higher productivity" in recent data, also the historical evidence provides little or no support ${ }^{8}$

\subsection{Copyright and Music in the $18^{\text {th }}$ Century}

The effect of copyright is difficult to analyze because it is hard to get reliable data prior to the $19^{\text {th }}$ century. Copyright was already fairly ubiquitous across Europe early in the $19^{\text {th }}$ century, and its term there has changed little since then.

The one exception turns out to be in the case of classical music. Copyright was unknown in the world of music until around the end of the $18^{\text {th }}$ century. As a result, a large proportion of classical music, still today accounting for about $3 \%$ of all music sales but, obviously, a much larger portion of music production until late in the $19^{\text {th }}$ century, was produced without the benefit of copyright protection.

Here is what Frederic Scherer, a strong supporter of intellectual property, has to say about in his extensive study of classical music:

The evolution of copyright from an occasional grant of royal privilege to a formal and eventually widespread

\footnotetext{
${ }^{8}$ To read more, a few good books to begin with are Epstein and Maarten [2005, eds.], Khan [2005, Chapter 2], Landes [1969] and Landes [1998]. A recent and fairly unbiased synthesis of the historical literature concerned with the impact of patents on the Industrial Revolution and inventive activity during the $18^{\text {th }}$ and $19^{\text {th }}$ century, McLeod and Nuvolari [2006], concludes by saying

However, it would be wrong to assume that the emergence of patent systems played a critical or determinant role in such a transition. The evidence discussed in this paper has shown that the institutional arrangements supporting inventive activities in this historical phase were extremely variegated and sophisticated. [...] In other words, the roots of western industrialization seem to have been wider and deeper than the emergence of modern patent systems.
} 
system of law should in principle have enhanced composers' income from publication. The evidence from our quantitative comparison of honoraria received by Beethoven, with no copyright law in his territory, and Robert Schumann, benefiting from nearly universal European copyright, provides at best questionable support for the hypothesis that copyright fundamentally changed composers' fortunes. From the qualitative evidence on Giuseppe Verdi, who was the first important composer to experience the new Italian copyright regime and devise strategies to derive maximum advantage, it is clear that copyright could make a substantial difference. In the case of Verdi, greater remuneration through full exploitation of the copyright system led perceptibly to a lessening of composing effort. ${ }^{9}$

Professor Scherer also exploited the variations between European countries copyright law regarding music to conduct a third natural experiment. He compared the average number of composers born per million population per decade in various European countries. Turning first to England, he considers the precopyright period 1700-1752, and the post copyright period 1767-1849. As controls he looks also at what happened in Germany, Austria and Italy in which there was no change in copyright during this period.

\begin{tabular}{|llll|}
\hline & Pre & Post & Ratio \\
\hline UK & 0.348 & 0.140 & 0.40 \\
\hline Germany & 0.493 & 0.361 & 0.73 \\
\hline Italy & 0.527 & 0.186 & 0.35 \\
\hline Austria & 0.713 & 0.678 & 0.95 \\
\hline
\end{tabular}

We see that the number of composers per million declined everywhere, but it declined considerably faster in the UK after the introduction of copyright than in Germany or Austria, and at about

\footnotetext{
${ }^{9}$ Scherer [2004] p.191. It should be apparent that everything we know about the impact of copyright on classical music we have learned from Scherer [2004], and his sources. An additional valuable reference for the details relative to the extension of the Statute of Anne to musical compositions is Carroll [2005].
} 
the same rate as Italy. So there is no evidence here that copyright increased musical output.

However, the evidence is mixed, because the same experiment in France is more favorable to copyright. In France the precopyright period is $1700-1768$, and the post copyright period is 1783-1849

\begin{tabular}{|llll|}
\hline & Pre & Post & Ratio \\
\hline France & 0.126 & 0.194 & 1.54 \\
\hline Germany & 0.527 & 0.340 & 0.65 \\
\hline Italy & 0.587 & 0.153 & 0.31 \\
\hline Austria & 0.847 & 0.740 & 0.86 \\
\hline \hline
\end{tabular}

Here we find that, in France, when copyright is introduced the number of composers per million increased substantially more than in other countries. This should be noted, as it is pretty much the only piece of evidence supporting the idea that copyright increased classical music production we have been capable of finding.

Looking more broadly at the entire European scene and at the careers of comparable composers living with or without copyright protection Scherer finds it difficult to conclude that copyright law was a significant factor, either way, in determining the amount of musical composition taking place. It may not have reduced the incentive to compose music, but it certainly did not increase it either: whatever the mechanism affecting composers' incentives, copyright protection was not an important part of it.

\subsection{Patents and Innovation in the $19^{\text {th }}$ Century}

Kenneth Sokoloff, together with Naomi Lamoreaux and Zorina Khan examined the role of patents in the U.S. in the $19^{\text {th }}$ and early $20^{\text {th }}$ century. In 1836 the U.S.

instituted an examination system under which, before granting patents, technical experts scrutinized applications for novelty and for the appropriateness of claims about invention. This procedure made patent rights more secure by increasing the likelihood that a grant for a specified technology would survive a court challenge, and may also have provided some signal about the significance of the new technology. Thereafter, both patenting and sales of patent rights boomed. ${ }^{10}$

10 Lamoreaux and Sokoloff [2002], pp. 7-8. The research work of Khan, Lamoreux and Sokoloff we mention is covered in a variety of articles and books, 
The aim of this research is to show that the patent system introduced in the U.S. after the 1830s created a well defined market for patents and technologies that did not exist previously, and that the creation of such a market led to an increase in the number of patents registered and traded. It should be observed that the institutional change that led to the booming of patenting and the sales of patent rights was to make it more difficult to get patents - quite the opposite of modern institutional changes. In addition, while this research makes it clear that the number of patent agents, and of inventors making use of their services, boomed, they also document that an important portion of the services was to assist inventors in getting patents, and in navigating the thicket of existing patents - socially wasteful activities that would be unnecessary in the absence of a patent system.

One important difficulty is in determining the level of innovative activity. One measure is the number of patents, of course, but this is meaningless in a country that has no patents, or when patent laws change. Petra Moser gets around this problem by examining the catalogs of innovations from $19^{\text {th }}$ century World Fairs. Of the catalogued innovations, some are patented, some are not, some are from countries with patent systems, and some are from countries without. Moser catalogues over 30,000 innovations from a variety of industries.

Mid-nineteenth century Switzerland [a country without patents], for example, had the second highest number of exhibits per capita among all countries that visited the Crystal Palace Exhibition. Moreover, exhibits from countries without patent laws received disproportionate shares of medals for outstanding innovations. ${ }^{11}$

Moser does, however, find a significant impact of patent law on the direction of innovation

The analysis of exhibition data suggests that patent laws may be an important factor in determining the direction of innovative activity. Exhibition data show that countries without

including the book by Khan [2005], which contains a large bibliography. On the growth of intermediaries and their role see Lamoreaux and Sokoloff [2002].

${ }^{11}$ Moser [2003], p. 3. 
patents share an exceptionally strong focus on innovations in two industries: scientific instruments and food processing. At the Crystal Palace, every fourth exhibit from a country without patent laws is a scientific instrument, while no more than one seventh of other countries innovations belong to this category. At the same time, the patentless countries have significantly smaller shares of innovation in machinery, especially in machinery for manufacturing and agricultural machinery. After the Netherlands abolished her patent system in 1869 for political reasons, the share of Dutch innovations that were devoted to food processing increased from 11 to 37 percent. ${ }^{12}$

Moser then goes on to say that

Nineteenth-century sources report that secrecy was particularly effective at protecting innovations in scientific instruments and in food processing. On the other hand, patenting was essential to protect and motivate innovations in machinery, especially for large-scale manufacturing. ${ }^{13}$

It is interesting also that patent laws may reflect the state of industry and innovation in a country

Anecdotal evidence for the late nineteenth and for the twentieth century suggests that a country's choice of patent laws was often influenced by the nature of her technologies. In the 1880s, for example, two of Switzerland's most important industries chemicals and textiles were strongly opposed to the introduction of a patent system, as it would restrict their use of processes developed abroad. ${ }^{14}$

More recent work by Moser, ${ }^{15}$ exploiting the same data set from two different angles, strengthens this finding - that is, that patents did not increase the level of innovation. In her words: "Comparisons between Britain and the United States suggest that even the most fundamental differences in patent laws failed to raise the proportion of patented innovations." ${ }^{16}$ Her work appears to

\footnotetext{
12 Ivi, p. 6.

${ }^{13}$ Ivi, p. 6.

14 Moser [2003], pp. 34-35. Petra Moser's dissertation, which won the 2003 Gerschenkron Prize awarded by the Economic History Association to the best dissertation in the field, is a mine of valuable information on the role of patents in determining innovative activity during the 19 th and early 20 th century. The main findings are summarized in Moser [2003]

15 Moser [2005, 2006].

${ }^{16}$ Moser [2006], Abstract.
} 
confirm two of the stylized facts we often insist upon. First that, as we just mentioned in discussing the work of Sokoloff, Lamoreaux and Khan, innovations that are patented tend to be traded more than those that are not, and therefore to disperse geographically farther away from the original area of invention. Based on data for the period 1841-1901, innovation for industries in which patents are widely used is not higher but more dispersed geographically than innovation in industries in which patents are not or scarcely used. Second, when the "defensive patenting" motive is absent, as it was in 1851, an extremely small percentage of inventors (less than one in five) chooses patents as a method for maximizing revenues and protect intellectual property.

Summing up: careful statistical analyses of the $19^{\text {th }}$ century's available data, carried out by distinguished economic historians, uniformly shows two things. Patents neither increase the rate of innovation, nor are the best instrument to maximizes inventors' revenue. Patents create a market in patents and in the legal and technical services required to trade and enforce them.

\subsection{Patents and Innovation in the $20^{\text {th }}$ Century}

A number of studies have attempted to examine whether introducing or strengthening patent protection leads to greater innovation using data from post WWII advanced economies. We have identified twenty three economic studies that have examined this issue empirically. ${ }^{17}$ The executive summary: they find weak or no evidence that strengthening patent regimes increases innovation; they find strong evidence that strengthening the patent regime increases ... patenting! They also find evidence that, in countries with initially weak IP regimes, strengthening IP increases the flow of foreign investment in sectors where patents are frequently used.

\footnotetext{
${ }^{17}$ All the empirical studies listed in the long table can be found in the references at the end. The data about patents come from the 2003 Annual Report of the USPTO, which can be found on line at //www.uspto.gov/web/offices/com/annual, additional basic data is from www.cms.hhs.gov.
} 


\begin{tabular}{|llll|}
\hline Authors & Years & Country & Industry \\
\hline Arora et al [2003] & $1990-2002$ & U.S. & Many \\
\hline Arundel & Many & Many & Many \\
\hline Baldwin and Hanel & 1993 & Canada & Many \\
\hline Bessen and Hunt & $1980-1996$ & U.S. & Software \\
\hline Branstetter and Sakakibara & $1988-1998$ & Japan & Many \\
\hline Gallini & 1980 s & U.S. & Many \\
\hline Hall and Ham & $1980-1994$ & U.S. & Semiconductor \\
\hline Hall an Zeidonis & $1979-1995$ & U.S. & Semiconductor \\
\hline Jaffe & Many & Many & Many \\
\hline Kanwar and Evenson & $1981-1990$ & Many & Aggregate \\
\hline Kortum and Lerner & $1980-2000$ & U.S. & Many \\
\hline Lanjouw & $1990 s$ & India & Pharmaceutical \\
\hline Lanjouw and Cockburn & $1975-1996$ & India & Pharmaceutical \\
\hline Leger & $1978-2000$ & Mexico & Agriculture \\
\hline Lerner-1 & $1850-2000$ & Many & Many \\
\hline Lerner-2 & $1971-2000$ & U.S. & Financial \\
\hline Levine and Saunders & $1981-2001$ & U.S. & Software \\
\hline Licht and Zoz & 1992 & Germany & Many \\
\hline Lo & c. 1986 & Taiwan & Many \\
\hline Mann & $1900-2002$ & U.S. & Software \\
\hline Park & $1987-1995$ & OECD & Many \\
\hline Qian & $1979-1999$ & Many & Pharmaceutical \\
\hline Sakakibara and Branstetter & $1988-1995$ & Japan & Many \\
\hline Scherer and Weisbrod & $1970 s$ & Italy & Pharmaceutical \\
\hline
\end{tabular}

The authors who find the strongest effect on innovation of increased patent protection are Kanwar and Evenson, and Lo. The latter examines the 1986 reform in Taiwan, while the former use time series data from a cross section of countries to regress $R \& D$ as a fraction of GDP on various variables including a qualitative measure of IP protection. Both sets of results are worth examining a bit more closely than the rest.

Lo finds increased innovation by Taiwanese inventors as measured by R\&D expenditure and by the number of U.S. patents they were awarded. However, given the worldwide surge in U.S. patents about this time and the fact that the number of Taiwanese patents awarded to these same inventors did not much increase, we can neither reliably conclude that the effect of the 1986 law was an increase in innovation, nor a jump in aggregate or sectorial productivity. What the reform certainly did, and Lo documents this 
convincingly, was to increase the number of patents awarded to Taiwanese firms, especially in the U.S., which is altogether not surprising. Lo himself points out that the main channel through which the Taiwanese reform had a positive effect was by fostering foreign direct investment in Taiwan especially in those sectors in which patents are widely used.

This is an important point, which deserves a separate comment. In a world in which strong patent protection in some countries co-exists with weak protection in others, a country that increases patent protection should observe an increase in the inflow of foreign investment, especially in those sectors where patented technologies are used. Profit maximizing entrepreneurs always choose to operate in those legal environments where their rights are the strongest. In the U.S., for example, economists and people with common sense alike, have long argued that the policy of offering tax incentives and subsidies to companies that relocate in one state or another is not a good policy for the United States as a whole. Nobody denies that, if you provide a company with high enough subsidies and tax incentives, it will probably take them and relocate to your state, at least temporarily. The problem is that, after you do so, other states will respond by doing the same, or more. In the ensuing equilibrium, the total amount of investment is roughly the same as when no one was offering a subsidy, but everyone is now paying a distorting tax to finance the subsidy. When capital moves freely across countries, the very same logic applies to the international determination of IP rights. In what economists call the Nash Equilibrium of this game, it is obvious that patent holders prefer to locate in countries with strong IP laws. This increases the stock of capital in the receiving country and reduces it everywhere else, especially in countries with low IP protection. Hence, absent international cooperation, the strong incentive of most countries to keep increasing patent protection, even in the absence of lobbying and bribing by intellectual monopolists.

As for the study by Kanwar and Evanson, they have data on 31 countries for the period 1981-1990. Using two 5 year averages they find support for the idea that higher protection leads to higher R\&D as a fraction of GDP. Their measures of IP protection do not always seem to make sense, but this is not the proper place to engage in a statistical debate. There are five levels of IP protection and $\mathrm{R} \& \mathrm{D}$ as a fraction of GDP ranges from a ten year average of $.231 \%$ in Jordan to $2.822 \%$ in Sweden. They find that increasing IP by one level raises $\mathrm{R} \& \mathrm{D}$ as a fraction of GDP between $0.6 \%$ to 
$1.0 \%$. As before, the most favorable interpretation of this result is that countries offering higher levels of IP protection also attract investments in those sectors in which $R \& D$ and patents are most relevant. A less favorable interpretation of this result, instead, points out that Kanwar and Evenson have forgotten to include a main determinant of the ratio of R\&D to GDP: that is, market size as measured by GDP. The most elementary theory of innovation, either under competition or under monopoly, shows that the innovative effort is increasing in the size of the market, and that large and rich countries will invest a larger share of their GDP in R\&D compared with small and poor countries. Putting Kanwar and Evanson's data together with GDP data from the 1990 CIA World Fact Book, we find that a $1 \%$ increase in the size of a country as measured by GDP increases the ratio of R\&D to GDP by $0.34 \%$.

It is interesting to looks at the residual error that is left over after we predict the ratio of (the logarithm of) R\&D to GDP from (the logarithm of) GDP. Sorted by IP level we find

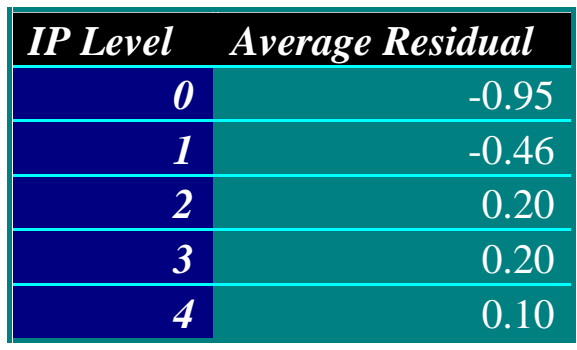

What does this show? The question is whether increasing the IP level leads to an increase in the residual. Moving from level 0 to 1 and from level 1 to level 2 this is true, but not moving from 2 to 3 or 3 to 4 . In other words, once you control for market size, higher IP protection increases the R\&D/GDP ratio at the very low levels, but becomes uncorrelated with the R\&D/GDP ratio at any level of IP protection equal to 2 or more in the Kanwar and Evenson scale. This reinforces the idea that what we are seeing is primarily the effect of foreign investment. Among poor countries with low IP protection, increases bring in more foreign investment and raise $R \& D$. In richer countries with high levels of IP, foreign investment is not an issue, and increases in IP have little or no effect on innovation.

\subsection{Data Bases}

The case of databases is still an experiment in the making, or at least it was until about five years ago. Unusually enough, the 
U.S. is, at least for now, on the right side of the divide. Databases, it seems obvious, have become increasingly important for private individuals, businesses, academic researchers, industrial R\&D and, unfortunately, also for national security.

The experiment-in-the-making and the intense debate accompanying it, both began in 1996. On March 11, the European Union issued a directive requiring member states to provide statutory protection of data-bases on the basis of copyright, even if the data base in question contained material that was not itself under copyright. The E.U. also tried to force nonmember states to accept its directive. It did this by deciding that EU protection would be extended to their citizens only if the nonmember states provided similar protection. By 2001 all EU countries had fully implemented the EU directive.

Which one do you think is higher: The rate of creation of databases in the E.U. - where they are protected by IP - or in the U.S. - where they are not? Well, you guessed right: in the U.S. In fact, it is not even a race, the U.S. wins hands down, as Block points out. After documenting in details the excellent state of the database industry in the U.S., its amazing growth rate and productivity as well as the fact that the adoption of the directive does not seem to have produced any sustained increase in the E.U.'s production of databases, Block adds

For the entire period measured, U.S. online database production outpaced all of Europe by a factor of nearly 2.5:1 ... American dominance of database production cannot be explained by incentives given to creators because American protection of database rights is much weaker than the Directive. ${ }^{18}$

To which we only add that, most probably, American dominance of the industry can be explained by economic incentives to creators as measured by the actual profits accruing to them and by the competitive environment in which they operate, and that, almost certainly, neither of them is increased much by the EU Directive.

\section{Abolition}

Defenders of intellectual monopoly like to portray intellectual property as a powerful and beneficial medicine. If a

${ }^{18}$ Block [2000], p. 7. 
medicine has serious side effects and scientific studies have found at best weak evidence of temporary benefits, would you employ such a drug on an otherwise healthy patient? Probably not, unless the illness was life threatening. Yet we have documented that innovation thrives in the absence of intellectual monopoly (the patient is healthy), that the latter has serious side effects (the evils of intellectual monopoly) and that a series of scientific studies have found weak or no evidence that it increases innovation (the proposed beneficial effect is probably absent).

"On the basis of the present knowledge" progressively but effectively abolishing intellectual property protection is the only socially responsible thing to do. Evidence has accumulated during the last fifty years leaving little doubt about the damaging effects of current intellectual property laws. At the same time, legal, economic, and business know-how has also accumulated about how markets for innovation operates without intellectual monopoly. To rule out abolition a priori would be no more sensible now than it would have been to rule out the abolition of tariffs and trade barriers fifty years ago, when the trade liberalization process that has given us prosperity and globalization began. For a long time, the individuals and firms that profited from trade barriers argued that these increased the wealth of the nation, defended homeland companies and jobs, and that abolishing them would lead to a disaster for many sectors of our economy. It took a while to realize this was not true, and that trade barriers were nothing more than rent-seeking devices, favoring a minority and dramatically hurting the overall economy and everyone else, beginning with low income consumers. The same is now true of patents and copyright.

Which leads us to address, albeit very briefly, another concern raised by Mark Lemley in his contribution: that we grossly overstate the positive impact that competition may have had, or would have, on innovative activity. Again, this may well be true, but there is no empirical evidence whatsoever in the literature that this is the case. In our book we provide dozens of examples of competitive industries that are highly innovative and are so because they are open to free entry and competition. The list goes from the very important in terms of GNP (software at its origin or the financial industry until now or the whole of agriculture until the 1970s) to the somewhat secondary or even marginal (the pornography industry and fashion design) or, why not, our own industry: academic research is based and thrives on open competition. Our critics, we insist, may well be right but the 
burden of the proof is now on their shoulders. It is up to them to prove, with data and facts, that our examples are distorted or irrelevant or special. Until that is done we can only remind the reader that, for various centuries, the very same negative and dismissive evaluation of the power of competition had been opposed to advocate of free trade. The last century and a half are there to prove who was right and who was wrong.

Therefore, while waiting for an empirical proof that competition harms innovation or fosters it very little, let us move on to the main issue: is it worth advocating the abolition of patents and copyright? Scientific studies of the current system agree that it is badly broken. Getting rid of it may therefore be a good idea. Still, one should pause. Realizing that intellectual monopoly may be akin to cancer, we recognize that simply cutting it all out at once poses problems. Since intellectual property laws have been around for a long while, we have learned to live with them. A myriad of other legal and informal institutions, business practices and professional skills have grown up around them and in symbiosis with them. Consequently, a sudden elimination of intellectual property laws may bring about collateral damages of an intolerable magnitude.

What this example suggests is that abolition must be approached by smaller steps, and that the sequencing of steps matters. Gradual reform is necessary both because of the need for other institutions, to reform in parallel, and also because it is a political necessity. The number of people prospering thanks to intellectual monopoly is large and growing. While some of them, such as movie stars, have accrued much wealth, for many others this is not the case. For many ordinary people intellectual monopoly has become another way of earning a living and, while most of them would be able to earn an equally good or even better living without it, many others need time to adjust. Further, and again in analogy with trade barriers, while the number of people who would benefit from the elimination of intellectual monopoly is large and growing, the gain each one of them perceives as likely is small. In spite of the brouhaha surrounding the "pirating" of popular music and movies, the direct personal saving from copyright reduction or even abolition would not be substantial as music, movies and books are a tiny share of household consumption. In the case of medicines and software, consumers' potential saving may be more substantial but harder to perceive. Finally, and most importantly, if in the 1950s or 1960s the average citizen of the world could hardly forecast the tremendous 
improvement in her standard of living that free trade would have brought about within thirty years, even harder it is now to perceive the incremental technological advances that a progressive elimination of intellectual monopoly could bring about in a couple of decades.

In summary, dismantling our intellectual property system poses a set of circumstances that the literature on collective action has identified as major barriers to reform. A few, well-organized and coordinated monopolists on the one side are bound to lose a lot if the protective barriers are lifted. A very large number of uncoordinated consumers on the other side, would receive very small personal gains from the adoption of freer competition. For a long time then, the battleground is going to be one of competing ideas and theories aimed at convincing public opinion that substantial gains are possible from the elimination of intellectual monopoly. In the mean time, there is a vast array of ideas both for greatly expanding intellectual property and, in the opposite direction, for useful reform. In this, our concluding, chapter, we try to sort these proposals into the bad, the good, and the just plain ugly.

\section{Bad Policy}

Despite the fact that our system of intellectual property is badly broken, there are those who seek to break it even further. The first priority must be to stem the tide of rent-seekers demanding ever greater privilege. Within the United States and Europe, there is a continued effort to expand the scope of innovations subject to patent, to extend the length of copyright, and to impose ever more draconian penalties for intellectual property violation. Internationally, the United States - as a net exporter of ideas - has been negotiating dramatic increases in protection of U.S. intellectual monopolists as part of free trade agreements.

There seems to be no end to the list of bad proposals for strengthening intellectual monopoly. To give a partial (and dated, as it was last compiled in 2007 and we do not have here the opportunity to update it) list starting with the least significant

- Extend the scope of patent to include sports moves and plays. ${ }^{19}$

\footnotetext{
${ }^{19}$ To the best of our knowledge, the first published statement of this proposal is in Kukkonen [1998], but a quick search on Google shows the idea is receiving lots of attention from interested lawyers and law firms, see Das [2000], http://www.mofo.com/news/updates/files/update1022.html.
} 
- Extend the scope of copyright to include news clips, press releases and so forth. ${ }^{20}$

- Allow for patenting of story lines - something the U.S. Patent Office just did by awarding a patent to Andrew Knight for his "The Zombie Stare" invention. ${ }^{21}$

- Extend the level of protection copyright offers to databases, along the lines of the 1996 E.U. Database Directive, and of the subsequent WIPO's Treaty proposal. ${ }^{22}$

- Extend the scope of copyright and patents to the results of scientific research, including that financed by public funds; something already partially achieved with the Bayh-Dole Act. ${ }^{23}$

a Extend the length of copyright in Europe to match that in the U.S. - which is most ironic, as the sponsors of the CTEA and the DMCA in the USA claimed they were necessary to match ... new and longer European copyright terms. ${ }^{24}$

- Extend the set of circumstances in which "refusal to license" is allowed and enforced by anti-trust authorities. More generally, turn around the 1970's Antitrust Division wisdom that lead to the so called "Nine No-No's" to licensing practices. Previous wisdom correctly saw such practices as anticompetitive restraints of trade in the licensing business. Persistent and successful, lobbying from the beneficiaries of intellectual monopoly has managed to turn the table around, portraying such monopolistic practices as "necessary" or even "vital" ingredients for a well functioning patents' licensing market. ${ }^{25}$

${ }^{20}$ As in the Spanish case of Gedeprensa.

21 The recent extension of patents to story lines is discussed in www.emediawire.com/releases/2005/11/emw303435.htm. For a, more than sympathetic but highly revealing in its biasedness, legal "analysis" of the whole idea of patenting plots, visit http://www.plotpatents.com/legal_analysis.htm, which comes directly from the law firm that worked hard to patent fictional plots.

${ }^{22}$ As we discussed in Chapter 8 of our book and references therein.

${ }^{23}$ There is no need for references here, still here is one to an old and rather interesting case of University research patenting, Apple [1989].

${ }^{24}$ Again, material abounds on the web and the regular press about the ongoing debate to extend the EU copyright term to match the current extended US term. To start, see http://news.bbc.co.uk/1/hi/entertainment/music/3547788.stm. For a piece by Dennis Karjala on EU-US harmonization see http://homepages.law.asu.edu/ dkarjala/OpposingCopyrightExtension/legmats/ HarmonizationChartDSK.html.

${ }^{25}$ See http://www.usdoj.gov/atr/public/hearings/ip/chapter_1.pdf for a relatively technical discussion of the issues involved in the "unilateral refusal to licensing" practice. For a list of the "Nine No-No's", and a not unbiased discussion of the opportunity to dispose of them, clearly favoring the disposal option, see Gilbert and Shapiro [1997]. For a very different view, cogently applied to the two recent Microsoft antitrust cases, see First [2006]. 
- Establish, as a relatively recent U.S. Supreme Court ruling in the case of Verizon vs Trinko did, that legally acquired monopoly power and its use to charge higher prices is not only admissible, it "is an important element of the free-market system" because "it induces innovation and economic growth."

- Impose legal restrictions on the design of computers forcing them to "protect" intellectual property. ${ }^{26}$

- Make producers of software used in P2P exchanges directly liable for any copyright violation carried out with the use of their software, something that may well be in the making after the Supreme Court ruling in the Grokster case. ${ }^{27}$

a Allow the patenting of computer software in Europe - this we escaped, momentarily, due to a sudden spark of rationality by the European Parliament. ${ }^{28}$

- Allow the patenting of any kind of plant variety outside of the United States, where it is already allowed. ${ }^{29}$

- Allow for generalized patenting of genomic products outside of the United States, where it is already allowed. ${ }^{30}$

${ }^{26}$ Information and news about the Digital Rights Management (DRM) initiative (in its multiple versions) and its very controversial nature are widespread on the web and on other media. The curious reader may want to begin with the relative Wikipedia entry and then continue from there.

${ }^{27}$ For detailed information about the Grokster case, Wikipedia is again a good starting point, while additional info can be found at the Electronic Frontier Foundation page on MGM v. Grokser. A middle-of-the-road legal assessment is in Samuelson [2004]. For the sad effect of the Supreme Court ruling on economic innovation, go to www.grokster.com and read the scary message welcoming you.

${ }^{28}$ On July 2, 2005 the European Parliament voted 648 to 14 (18 abstensions) to scrap the so-called "Directive on the Patentability of Computer Implemented Inventions." While this was good news, the battle on software patents in Europe is far from over. The vote is attributable more to a general fight with the EU Commission, tending to ignore whatever the European Parliament suggests, than to a widespread opposition to software patents within the latter body. In the meanwhile, though, grassroots opposition has grown and, especially within the business community, a variety of action groups have sprung up that oppose software patents along pro-business lines and on the basis of pro-free market arguments such as those exposed in this book.

${ }^{29}$ News and information on this topic are widespread through all kinds of media. The FAO on-line Forum on Biotechnlogy in Food and Agriculture, at $\mathrm{http} / / / \mathrm{www}$.fao.org/biotech/forum.asp, is a particularly informative starting point for the interested reader. A number of reasonable reforms that would improve the developing countries' situation in the agricultural sector can be found at http://issues.org/17.4/barton.htm.

${ }^{30}$ Having abundantly clarified why genomic patents are a bad idea, references to people liking them for misguided reasons are Putnam [2004] and Hale et al. [2006]. 
- Force other countries, especially developing countries, to impose the same draconian intellectual property laws as the U.S., the E.U. and Japan. ${ }^{31}$

Why these are bad ideas should be self-evident by now - and all should be rejected.

Developing countries in particular should be wary of negotiating away their intellectual freedom in exchange for greater access to U.S. and E.U. markets. Developing countries are, slowly but surely, giving in to the U.S. and E.U. pressure and modifying their national legislation in accordance with the requirements imposed by TRIPS and the WIPO. This is partly the effect of sheer lobbying and political pressure by Western governments and large multinationals. Partly, this is also due to the lack of a workable and coherent alternative to the over-reaching redesign of world intellectual property rights underlying TRIPS and its ideology. This trend makes an open and critical debate on such themes in developing countries even more urgent and valuable than it would be in any case.

\section{Good Policy}

There are a great many things that can be done to make modest improvements in the current system of both patents and copyrights. In the case of patents there are a variety of proposals for making the patent system less vulnerable to "submarine" patenting, and generally tightening up the system so that a patent has some real connection to innovation, and is not merely a claim to someone else's invention. In the case of copyright, a major priority is to make sure that all the abandoned and orphaned works do not forever remain unusable because they are under copyright, and the copyright holder is dead, has disappeared or is in any case untraceable.

For both patents and copyright, a fundamental priority is to prevent the public domain from shrinking further, and, when possible, push back the fences that are progressively enclosing it. This means, on the one hand, opposing new proposals for the extension of copyright term and coverage beyond those established by the 1998 Digital Millenium Copyright Act (DMCA) and

\footnotetext{
${ }^{31}$ This being the main, if not the only, reason behind the existence of TRIPSWTO, as is easily verified from the documents contained on the TRIPS web site at http://www.wto.org/english/tratop_e/trips_e/trips_e.htm.
} 
Copyright Term Extension Act (CTEA). On the other hand, it also means to take proactive actions to defend from rapacious hands what is growing in the public domain and needs to be nurtured. Private economic initiative can be extremely useful along this dimension and the recent Open Innovation Network initiative, led by IBM, is a wonderful case in point. ${ }^{32}$

Jaffe and Lerner document in great detail how the patent system, as it is currently implemented in the U.S., is broken. ${ }^{33}$ They make numerous proposals to make frivolous patents more difficult to get and enforce. We support these proposals in principle - and while we might disagree over some of the details, we expect that were we to debate the matter, they would convince us on some points, and we would convince them on others.

One proposal in particular, is to allow patents to be challenged before they are granted. This would allow real evidence to be brought to bear on the issue of prior art - something the U.S. Patent Office seems to know little about, as the thousands of "how to swing a swing" and "peanut-butter and jelly sandwiches" patents suggest. ${ }^{34}$ Realistically, however, few individuals or firms would be likely to monitor the patent system carefully enough to identify bad patents, or to incur the expense of providing the public good of challenging bad patents. Quillen et $\mathrm{al}^{35}$ examine the rigor with which the U.S. Patent Office carries out its examining activities and compare it to those of the European and Japanese Patent Offices. They take the opposite approach from Lerner and Jaffe, suggesting that the patent office is not the appropriate place

${ }^{32}$ Information about the IBM and other companies' protective patent pool on Linux is widespread through the web and other media. Visit Wikipedia under OSDL and Free Standards group to learn more, or go directly to the sites of the OIN, http://www.openinventionnetwork.com and of the Linux Foundation http://www.linux-foundation.org/en/Main_Page.

33 A detailed discussion of possible, and all very reasonable, reforms can be found in Jaffe and Lerner [2004].

${ }^{34}$ Obviously, the "how to swing a swing" patent (United States Patent 6368227) is here just a label for a gigantic, and ever growing, class of patents that are so logically unfounded that one may think we fabricated the whole thing. Well, we must admit that we do not have the level of imagination needed to reach the heights achieved by the USPTO in cooperation with some of the most shameless rent-seekers in the world. For entertaining surveys of this modern set of legal monstrosities, out of an almost endless list of sites, the following few: www.freepatentsonline.com/crazy.html, www.crazypatents.com, www.totallyabsurd.com, www.patentlysilly.com should keep you amused if not frightened.

${ }^{35}$ Quillen et al [2002]. 
to reach decisions concerning patentability. They conclude by asking

...why should we not go to a registration system and avoid the expenses of operating an examination system ... shouldn't we abolish continuing applications so that the USPTO will be able to obtain final decisions as to the patentability of subject matter presented in patent applications and avoid having rework imposed upon it. Finally, so long as the USPTO grants a patent for virtually every application filed, are the courts justified in adhering to the clear and convincing evidence standard for overcoming the statutory presumption of validity? $?^{36}$

It is striking but true that either of these proposals, although they go in opposite directions, would be an improvement over the current system. That speaks volumes about how bad the current system is: mathematicians call it a "global minimum" a position such that any movement away from it, in any direction, improves things. This is another such case.

Also of great significance is the proposal of Gallini and Scotchmer to allow the "independent invention" defense to patent claims ${ }^{37}$. That is, they would allow proof that an invention was independently derived, and not obtained directly or indirectly as a consequence of the similar invention that was patented first, as a defense against patent infringement. For example, if you patented the "one-click" with the mouse to past text into a word processor, and sued me because my word processor also pasted text with just one click, I could defend myself by showing that I had written my word processor in my spare time and had never read your patent, or seen a copy of your word processor. This would not only relieve the innovator from concern that in his ignorance he would run afoul of some existing patent, it would also make it substantially more difficult to engage in submarine warfare, as the inventor who is torpedoed by the submarine could argue, and prove, that his invention was independent. This reform, alone, would be of great social value and would enormously reduce the burden of intellectual monopoly. As we have illustrated repeatedly, simultaneous or independent inventions are almost the rule in the

\footnotetext{
${ }^{36}$ Quillem et al [2002], pp. 50-51.

${ }^{37}$ Gallini and Scotchmer [2001].
} 
creative process, rather than the exception. For many great inventions of the last century - the radio, the TV, the airplane, the telephone - allowing the two or more independent and simultaneous inventors to both exploit their invention commercially would have greatly benefited consumers and economic progress in general. This is even more true and more relevant today, as the number of judicial disputes over practically identical and simultaneous innovations skyrockets, especially in the fields of software, biomedical products and telecomunications, and for business practices in general.

An alternative reform would be to require mandatory licensing at fees based on estimates of $R \& D$ costs. The principle is the following: if it costs $\$ 100$ to invent a gadget, $10 \%$ is a reasonable rate of return on this type of investment, and expected demand for licensing is in the order of 100 units, then a net present value fee of $\$ 1.10$ would be right. If the cost of uncertainty is an additional five cents we should set mandatory licensing fee at $\$ 1.15$ for this particular patent. William Kingston takes a more serious look at how this might work in practice, particularly figuring a multiplier to account for the many failed innovations needed to produce a successful one. Kingston points out that cost estimates are already widely used in patent litigation and are not so difficult to produce and document. He estimates that, for most of the cases he studied, the total revenue from licensing products that are successfully patented and licensed should be about eight times their R\&D cost, if the license is taken immediately; for licenses issued as the products actually go to market, a multiplier of four would be more appropriate. In the case of pharmaceuticals, he suggests a multiple of two would be sufficient - noting that

If three such licenses were taken, the payments would [already] put the product into the most profitable decile (the home of the blockbuster drugs). ${ }^{38}$

A backdoor to reducing the term of patent, and making it less easy to accidentally run afoul of long-standing but meaningless patents, would be to reintroduce patent renewal - for example, keeping the term of patent fixed, while splitting the twenty year term into smaller increments, with a renewal required

${ }^{38}$ Kingston [2001] p. 32. 
at each stage. This is discussed by Cornelli and Schankerman and by Scotchmer. ${ }^{39}$

In copyright, the most immediate problem is that of an Administration, a Congress and a Supreme Court that are "bought and paid for." The triple whammy of giving automatic copyright to every work, whether or not it is registered, eliminating the need for renewal, and extending the term of copyright to be essentially infinite means that, over time, virtually everything written will become inaccessible. The Obama Admnistration is now taking care of spreading this gospel around the world by placing such issues as "getting tough on pirates" at the top of its diplomatic agenda. Lessig $^{40}$, among others, documents in great detail the problems caused by these "ugly reforms." He proposes that some of the illeffect could be undone by a modest renewal fee. Landes and Posner $^{41}$ suggest that the legal principle of abandonment could be applied to copyright holders who do not actively make it clear that they are maintaining their copyright. Either or both of these proposals - however politically naïve they might be - would be a great improvement over the current situation.

The debacle we currently face in copyright is that as more and more draconian laws concerning copyright are introduced, less and less real copyright protection is possible, as it has proven impossible to police the $\mathrm{P} 2 \mathrm{P}$ networks in any realistic sense. Many have suggested that the way out of this dilemma is through mandatory licensing. Radio broadcasters currently pay a fixed fee, but do not require special permission to broadcast a song. In the same way, downloads could be made legal and payments to copyright holders based on the number of times a song is downloaded. This is not a perfect proposal - the possibility of manipulating the "download ratings" comes to mind, and the mandatory licensing fee for internet radio was set untenably high but on balance, would probably serve to improve the current situation.

The recent, and widely advertised if limited, decisions by Apple and EMI to renounce policing P2P file sharing via technological means (that is, by giving up on DRM) is also a positive step. It signals that at least a few among the big players are realizing that the "technological police" approach is a losing

\footnotetext{
39 Patent renewal schemes are discussed in Cornelli and Schankerman [1999] and Scotchmer [1999].

${ }^{40}$ Lessig [2004]. See especially the chapter "Registration and Renewal" in the public domain version at http://www.authorama.com.

${ }^{41}$ Landes and Posner [2003].
} 
business proposition, and that plenty of money can be made by selling downloadable music that consumers can then share and redistribute more or less freely. ${ }^{42}$

\section{Subsides for Innovation and Creation}

It is theoretically possible that the competitive market alone provides insufficient incentive to innovate - although, as we already said, there is no evidence that this is the case. Suppose that we succeed in abolishing intellectual monopoly and discover, after a few years, that there is less innovation than would be socially desirable. Unlikely as this event may be, we as economists must nevertheless consider it. Hence, should we reintroduce intellectual monopoly in this case?

Intellectual property law is about the government enforcing private monopolies. In countries without effective tax collection mechanisms, both historically and currently, government grants of monopolies were and are commonplace; we all have seen some old label for a tea or chocolate brand reporting "By Appointment of Her Majesty." As nations develop, more effective tax collection infrastructures have been replacing such revenue devices as the salt monopoly, or the grant of exclusive import rights to the brother-inlaw of the president. Hence, the sale by government officials of exclusive rights to carry out this or the other commercial activity or to produce and commercialize certain goods and services have progressively disappeared in almost all advanced market economies. Intellectual property is one of the few remaining anachronisms from the pre-history of modern tax collection, worse, indeed: it is a distorted anachronism that is now being exploited for rent-seeking purposes that are opposite to those for which it was originally established. The answer is that - if there is indeed a need for extra incentives - it should be done through subsidization and not through government grants of monopoly.

A first question might be what level of subsidy would replace the profits of the current monopolists? ${ }^{43}$ Schankerman $^{44}$

42 Mildly good legal news seem also to be coming from the European courts, which have started to rule against some of the most preposterous requests to treat any form of music downloading as theft, even when intended only for personal use and with no commercial purposes. For the Spanish and Italian court rulings see, for example, http://www.theregister.co.uk/2006/11/03/spanish_judge_says_downloading_leg al/ and http://www.repubblica.it/2006/10/sezioni/cronaca/cassazione-3/lecitoscaricare-file/lecito-scaricare-file.html 
makes the calculation that a subsidy to $\mathrm{R} \& \mathrm{D}$ of $15 \%-35 \%$ would be enough to provide an incentive equivalent to that currently provided by patents - ironically subsidies of nearly this level are already available in addition to patents, especially in the pharmaceutical industry, as we documented in the previous chapter. Indeed, the offensive sight of the government using taxpayers' money to subsidize research and then awarding it a private monopoly reaches absurd heights in academia, where in recent years the mantra of "private-public partnership" has taken hold. A more egregious form of public subsidy for private monopolies is hard to imagine.

Like monopolies, subsidies can lead to rent-seeking and have distortionary effects, so they should scarcely be a first resort. Some economists, such as Paul Romer, painfully aware of these negative side-effects, have proposed to avoid some of these distortions by narrowly targeted subsidies - for example to graduate students who, the evidence suggests, are key instruments in the process of innovation. Others, such as Andreas Irmen and Martin Hellwig, suggest that broad subsides to investment in general - interest rate subsidies, for example - are likely to be the least distortionary. Yet others, such as Michael Kremer, suggest that prizes awarded after the fact create greater incentives to innovate. Nancy Gallini and Suzanne Scotchmer go further and compare various subsidization methods in their recent work. Their technical analysis is beyond the scope of this book, but the basic point remains: various intelligent forms of subsidizing basic research and even applied invention exist, and an appropriate mix

43 Schankerman and Pakes [1986] have studied patent returns in various European countries. Using their data, Kingston [2001] estimates the subsidies that would be required to replace the current patent system (p. 18)

Schankerman and Pakes reported that for patents in Britain, France and Germany, the returns appear to be only a small fraction of the domestic $R \& D$ expenditure of the business enterprises. The means of the discounted sum of rewards from patent age 5 were about \$7,000 in Britain and France and $\$ 19,000$ in Germany. The value of patents as a proportion of total national $R \& D$ expenditure was 0.057 in France, 0.068 in Britain and 0.056 in Germany (1986, pp. 1068, 1074). Schankerman subsequently estimated that a subsidy to R\&D of $15 \%-35 \%$ would be enough to provide an equivalent incentive to patents (1988, p. 95).

44 Schankerman [1998]. Notice that this is the same paper referred to by Kingston in the quotation reported in the previous note; 1988 is clearly a typo in Kingston's working paper. 
can be found that would greatly improve upon patents and copyright. $^{45}$

\section{Ugly Policy}

Whether the Disney Corporation will get to continue their monopoly of Mickey Mouse does not seem like an issue that should lead either to revolt or non-violent insurrection. But have no doubt - intellectual monopoly threatens both our prosperity and our freedom and to strangle innovation all together.

This might seem an exaggerated statement, made only to stir controversy - and sell a few more copies of our copyrighted book. Yet, despite the fact that by 1433 the great Chinese explorer Cheng Ho's fleets had explored Africa and the Middle East ${ }^{46}$, in the subsequent centuries the world was colonized by Europeans and not by the Chinese. The monopolists of the Ming Dynasty saw a threat to their monopoly - which was then a monopoly of intellectual and administrative power - in the innovative explorations of Cheng Ho and forced him to stop. This lead to a static, inward looking and regressive regime, where Emperors ruled under mottos such as "stay the course" and "do nothing", and where innovation and progress not only faltered, but were progressively replaced by obsolescence, regression, and, eventually, poverty. And so it is that in the United States we celebrate Christopher Columbus day, rather than Cheng Ho day.

At a smaller scale, but with a no less real impact on world history, we find that intellectual property has delayed the development of the steam engine, the automobile, the airplane, and innumerable other useful things. This took place at a time before the United States became the sole dominant world power, and before a system nearly as noxious as the current system in the United States and the European Union was in place. It took place during a time when very many countries were still competing for world primacy, and the collusive pact among intellectual monopolists that our modern trade agreements have been built to enforce, was not in the cards. If the Wright brothers preferred litigation to invention, at least the French were free to develop the airplane. If Gottlieb Daimler and Karl Benz were the first to build a practical automobile powered by an internal-combustion engine,

45 See, respectively, Romer [1996], Hellwig and Irmen [2001], Kremer [2001a,b] and Glennerster, Kremer and Williams [2006], Gallini and Scotchmer [2001].

46 To start learning about him, see, for example, http://famousmuslims.muslimonline.org/zheng-he-cheng-ho.html. 
their German patent did not prevent John Lambert, only six years later, from developing America's first gasoline-powered automobile. Nor did it prevent the Duryea Brothers, shortly after, from founding America's first company to manufacture and sell gasoline-powered vehicles. ${ }^{47}$

Where, today, is a software innovator to find safe haven from Microsoft's lawyers? Where, tomorrow, will be the pharmaceutical companies that will challenge the patents of "big pharma" and produce drugs and vaccines for the millions dying in Africa and elsewhere? Where, today, are courageous publishers, committed to the idea that accumulated knowledge should be widely available, defending the Google Book Search initiative? Nowhere, as far as we can tell, and this is a bad omen for the times to come. The legal and political war between the innovators and the monopolists is a real one, and the innovators may not win as the forces of "Stay the Course" and "Do Nothing" are powerful, and on the rise.

Certainly the basic threat to prosperity and liberty can be resolved through sensible reform. But intellectual property is a cancer. The goal must be not merely to make the cancer more benign, but ultimately to get rid of it entirely. So, while we are skeptical of the idea of immediately and permanently eliminating intellectual monopoly - the long-term goal should be no less than a complete elimination. A phased reduction in the length of terms of both patents and copyrights would be the right place to start. By gradually reducing terms, it becomes possible to make the necessary adjustments - for example to FDA regulations, publishing techniques and practices, software development and distribution methods - while at the same time making a commitment to eventual elimination.

Given that it may well be the case that some modest degree of intellectual monopoly is superior to complete abolition - why do we set as a goal complete elimination of intellectual property? Our position on intellectual monopoly is not different from the position most economists take on trade restrictions: although some modest amount of protection might be desirable in special cases, it is more practical and useful to focus on the elimination of restrictions as a general rule. Similarly, while some modest amount of intellectual

${ }^{47}$ Apart for two small entries on Wikipedia and a few other small sites, there is little on the web about either John Lambert or the Duryea Brothers. Still, by searching and reading carefully, their stories and their achievements do emerge slowly but surely. Neither of them took out a patent, but their innovative actions started the American automobile industry nevertheless. See Scharchburg [1993]. 
monopoly might be desirable in very special cases, it is more practical and useful to focus on the elimination of intellectual monopoly as a general rule. In innovation as in trade, a modest degree of monopoly is not sustainable. Once the lobbyist's nose is inside the tent, the entire lobby is sure to follow, and we will once again be faced with a broken patent system and absurdly long copyright terms. To secure our prosperity and freedom we must abolish intellectual monopoly from the tent entirely. To do so we must develop the very same patient determination with which we have been after trade restrictions for more than half a century, and we are not done yet.

This analogy between intellectual property and trade restrictions is not a purely rhetorical tool, nor a random comparison. For centuries, human innovative activity took the form of creating new consumption goods, new machines and new staples of food. But the transmission of ideas from one producer to another and across countries was not nearly as fast, standardized, and routinized as it is today. Creative human activity was focused on the creation and reproduction of physical goods and not on the creation and reproduction of ideas. Free trade of commodities was therefore key in fostering progress: the more competitors entered the market with shoes like yours, the more you had to improve on your shoes to keep selling them.

This dialectic we used to call economic progress, and, after a few centuries of intellectual debate and numerous wars, Western societies came to understand that restricting international trade was damaging because protectionism prevents economic progress and fosters international tensions leading to conflict. Since at least the late Middle Ages, the battle has been between the forces of progress, individual freedom, competition and free trade, and those of stagnation, regulation of individual actions, monopoly, and trade protection. Now that the intellectual and political battle over free trade of physical goods seems won, and an increasing number of less advanced countries are joining the progressive ranks of freetrading nations, pressure for making intellectual property protection stronger is mounting in those very same countries that advocate free trade. This is not coincidence.

Most physical goods already are and, in the decades to come, will increasingly be, produced in less developed countries. Most innovations and creations are taking place in the advanced world, and the IT and bio-engineering revolutions suggest this will continue for a while at least. It is not surprising then, that a new version of the eternal parasite of economic progress - mercantilism 
- is emerging in the rich countries of North America, Europe and Asia.

Economic progress springs from having things produced as efficiently as possible, so that they can sell at the lowest price. This wisdom applies to both the things we buy and to those we sell, and therein lies the trap of mercantilism. Most of us have learned that the surest way to make a profit is to "buy cheap and sell dear." When there is adequate competition and everyone tries to buy cheap and sell dear, then the only way I can buy cheap and sell dear is for me to be more efficient than you. This generates incentives for innovation and progress. The trap and tragedy of mercantilism is when this individually correct philosophy is transformed into a national policy: that we are all better off when our country as a whole buys cheap and sells dear. It was this myopic and distorted view of the way in which markets function that Smith, Ricardo, and the classic economists were fighting against 250 years ago. At that time wheat producers in England wanted to restrict free trade in wheat so English producers could sell it dear. That meant English consumers could not buy it cheap. Now, before moving to the next paragraph, consider the current debate about preventing "parallel imports" of medicines, CDs, DVDs, and other products covered by intellectual monopoly. Do you see a parallelism? That is our point.

The contemporary variation of this economic pest is one in which our collective interest is, allegedly, best served if we buy goods cheap and sell ideas dear. In the mind of those preaching this new version of the mercantilist credo, the World Trade Organization should enforce as much free trade as possible, so we can buy "their" products at a low price. It should also protect our "intellectual property" as much as possible, so we can sell "our" movies, software, and medicines at a high price. What this folly misses is that, now like three centuries ago, while it is good to buy "their" food cheap, if "they" buy movies and medicines at high prices, so do "we." In fact, as the case of medicines and DVDs prove, the monopolist sells to "us" at even higher prices than to "them." This has dramatic consequences on the incentives to progress: when someone can sell at high prices because of legal protection from imitators, they will not expend much effort looking for better and cheaper ways of doing things.

For centuries, the cause of economic progress has been identified with that of free trade. In the decades to come, sustaining economic progress will depend, more and more, upon our ability to progressively reduce and eventually eliminate intellectual 
monopoly. As in the battle for free trade, the first step must consist in destroying the intellectual foundations of the obscurantist position. Back then the mercantilist fallacy taught that, to become wealthy, a country must regulate trade and strive for trade surpluses. Today, the same fallacy teaches that without intellectual monopoly innovations would be impossible and that our governments should prohibit parallel import and enforce draconian intellectual monopoly rules. We hope that we have made some progress in demolishing that myth. 


\section{References}

Apple, R. [1989], "Patenting University Research: Harry Steenbock and the Wisconsin Alumni Research Foundation." Isis, Vol. 80, No. 3, pp. 374-394

Block, M. [2000], "The Empirical Basis for Statutory Database Protection After the European Database Directive", mimeo, Duke Law School, available at www.law.duke.edu/cspd/papers/empirical.doc

Boldrin, M. and D. K. Levine [2004a], "Rent Seeking and Innovation", Journal of Monetary Economics 51, 127-160.

Boldrin, M. and D. K. Levine [2004b], "2003 Lawrence Klein Lecture: The Case Against Intellectual Monopoly", International Economic Review 45, 327-350.

Boldrin, M. and D. K. Levine [2005a], "The Economics of Ideas and Intellectual Property", Proceedings of the National Academy of Sciences 102, 1252-56.

Boldrin, M. and D. K. Levine [2005b], "IP and Market Size", mimeo,

www.econ.umn.edu/ mboldrin//Research/Current_Researc h/innovation.html

Boldrin, M. and D. K. Levine [2006], "Standing on Giants's Shoulder. The Economics of Innovation in a Complex Economy", work in progress, Washington University in Saint Louis.

Boldrin, M and D.K. Levine [2007], "Full Appropriation and Intellectual Property," mimeo, Washington University in Saint Louis, February.

Carroll, M. W. [2005], "The Struggle for Music Copyright", Florida Law Review 57, 907-961.

Cornelli, F. and M.D. Schankerman [1999], "Patent Renewal and R\&D Incentives," RAND Journal of Economics, Vol. 30, 197-213.

Das, P.K. [2000], "Offensive Protection: The Potential Application of Intellectual Property Law to Scripted Sports Plays", Indiana Law Journal, Vol 75, 1073-1100.

Epstein, R.A. and B. N. Kuhlik [2004], "Is There a Biomedical Anticommons?" Regulation Magazine 27, 54-58.

Epstein, S.R. and P. Maarten [2005, eds.], Guilds, Technology and the Economy in Europe 1400-1800. London, U.K, Routledge.

Evans, D.S. and R.Schmalensee [2001], "Some Economic Aspects of Antitrust Analysis in Dynamically Competitive Industries", NBER Working Paper No. 8268. 
First, H. [2006], "Microsoft and the Evolution of the Intellectual Property Concept," New York University Law and Economics Working Papers, Year 2006, Paper 74

Gallini, N. [2002], "The Economics of Patents: Lessons from Recent U.S. Patent Reform", Journal of Economic Perspective 16, 131-154.

Gallini, N. and S. Scotchmer [2001], "Intellectual Property: When is it the Best Incentive System?" in Innovation Policy and the Economy, vol 2, ed. Adam Jaffe, Joshua Lerner and Scott Stern, MIT Press: Cambridge

Gilbert, R. and C. Shapiro [1990], "Optimal patent length and breadth," RAND Journal of Economics 21, 106-112.

Gilbert, R. and C. Shapiro [1997], "Antitrust Issues in the Licensing of Intellectual Property: the Nine No-No's Meet the Nineties," Brookings Papers on Economic Activity. Microeconomics, 283-336.

Glennerster, R., M. Kremer and H. Williams [2006], "Creating Markets for Vaccines," Innovations, Vol. 1(1): 67-79.

Hale, R., L. Tolleri and J.L. Telford [2006], "The evolution and impact of genome patents and patent applications," Expert Opinion on Therapeutic Patents, Vol. 16, No. 3, 231-235

Hellwig, M. and C. Irmen [2001], "Endogenous Technical Change in a Competitive Economy," Journal of Economic Theory 101, 1-39,

Hirshleifer, J. [1971], "The Private and Social Value of Information and the Reward to Inventive Activity" The American Economic Review 61, 561-574.

Hirshleifer, J. and J. G. Riley [1992], The Analytics of Uncertainty and Information, Cambridge University Press.

Jaffe, A.B. [2000], "The U.S. Patent System in Transition: Policy Innovation and the Innovation Process", Research Policy 29, 531-557.

Jaffe, A.B. and J. Lerner [2004], Innovation and Its Discontents, Princeton University Press.

Kanwar, S. and R. Evenson [2003], "Does Intellectual Property Protection Spur Technological Change?" Oxford Economic Papers 55,235-264

Karjala, D. S. [1998], "Statement of Copyright and Intellectual Law Professors in Opposition to H.R. 604, H.R. 2589 and S. 505, The Copyright Term Extension Act, Submitted to the Joint Committees of the Judiciary." January 28, 1998. Available at http://www.public.asu.edu/ dkarjala/legmats/1998Stateme nt.html.

Karjala, D. S. [2004], "Opposing Copyright Extension," www.public.asu.edu/ dkarjala/legmats/hatch $95 . h t m l$ 
Khan, Z. [2005], The Democratization of Invention. Patents and Copyrights in American Development, 1790-1920. Cambridge University Press.

Kingston, W. [1984], The Political Economy of Innovation, The Hague/Boston; reprinted: Martinus Nijhoff, 1989.

Kingston, W. [2001], "Meeting Nelson's Concerns about Intellectual Property." Paper presented at a Conference in Aalborg, June 12-15, 2001. Available at http://www.druid.dk/conferences/nw/

Kremer, M. [2001a], "Creating Markets for New Vaccines: Part I: Rationale," in Adam B. Jaffe, Josh Lerner, and Scott Stern (eds.), Innovation Policy and the Economy, MIT Press, Volume 1, 2001.

Kremer, M. [2001b], "Creating Markets for New Vaccines: Part II: Design Issues," in Adam B. Jaffe, Josh Lerner, and Scott Stern (eds.), Innovation Policy and the Economy, MIT Press, Volume 1, 2001.

Kukkonen, C. A. [1998], "Be a Good Sport and Refrain from using my Patented Putt: Intellectual Property Protection for Sports related Movements," J. Pat. \& Trademark Off. Soc'y 80, 808 .

Lamoreaux, N. R. and K. L. Sokoloff [2002], "Intermediaries in the U.S. Market for Technology, 1870-1920”, NBER Working Paper No. 9016

Landes, D. S. [1969], The Unbound Prometheus: Technological Change and Industrial Development in Western Europe from 1750 to Present. Cambridge University Press.

Landes, D. S. [1998], The Wealth and Poverty of Nations: Why Are Some So Rich and Others So Poor? W.W. Norton.

Landes, W.M. and R. Posner [2002], "Indefinitely Renewable Copyright," Olin Center for Law and Economics, the University of Chicago, Working Paper available at http://www.law.uchicago.edu/Lawecon/WkngPprs_151175/154.wml-rap.copyright.new.pdf.

Landes, W. M. and R. A. Posner [2003]: The Economic Structure of Intellectual Property Law, Harvard University Press.

Lemley, M. A. [2004], "Ex Ante versus Ex Post Justifications for Intellectual Property”, mimeo,UC Berkeley.

Lessig, L. [2004], Free Culture, Penguin Press.

Lo, S-T. [2004], "Strenghtening Intellectual Property Rights: Experience from the 1986 Taiwanese Patent Reforms", mimeo, UCLA, Dept. of Economics. Available on line at http://www.international.ucla.edu/article.asp?parentid=109 85

Machlup, F. [1958], "An Economic Review of the Patent System", Study of the Sub-Committee on Patents, Trademarks, and 
Copyrights of the Committee on the Judiciary. United States Senate, $85^{\text {th }}$ Congress, Second Session. Pursuant to S. Res. 236, Study No. 15.

MacLeod C. and A. Nuvolari [2006], "Inventive Activities, Patents and Early Industrialization. A Synthesis of Research Issues", DRUID w.p. No 06-28, www.druid.dk

Moser, P. [2003], "How do Patent Laws Influence Innovation? Evidence from Nineteenth-Century World Fairs", NBER working paper No. 9909, from which we quote. Published, in an abridged version, in The American Economic Review 95, 1215-1236.

Moser, P. [2005], "Do Patents Facilitate Knowledge Spillovers?

Evidence from the Economic Geography of Innovations in 1851", mimeo, NBER and MIT, available on line at http://web.mit.edu/moser/www/loc507nber.pdf.

Moser, P. [2006], "What do Inventors Patent?", mimeo, MIT and NBER, available on line at http://web.mit.edu/moser/www/patrat603.pdf

North D. C. [1981], Structure and Change in Economic History, Norton.

North, D. [1991], Institutions, Institutional Change and Economic Performance, Cambridge University Press

Putnam, J.D. [2004], "Cost and Benefits of Genomic Patents," American Journal of Pharmacogenomics, Vol. 4 (5), 277292.

Quillen, C.D.Jr., O.H. Webster, and R. Eichmann, "Continuing Patent Applications and Performance of the U.S. Patent and Trademark Office - Exended", The Federal Circuit Court Bar Journal, Vol. 12, No. 1, (August 2002), 35-55.

Romer, P. [1986], "Increasing Returns and Long Run Growth", The Journal of Political Economy 94, 1002-1003.

Romer, P. [1990a], "Are Nonconvexities Important for Understanding Growth?" The American Economic Review 80, 97-103.

Romer, P. [1990b], "Endogenous Technological Change," The Journal of Political Economy, 98, S71-S102.

Romer, p. [1996], :Science, Economic Growth and Public Policy," in B. Smith and C. Barfield, eds., Technology, $R \& D$, and the Economy, Brookings Institution and American Enterprise Institute.

Samuelson, P. [2004], "What's at Stak ein MGM vs. Grokster?" Communications of the ACM, Vol. 47, No. 2, 15-20.

Schankerman, M. [1998], "How valuable is patent protection? Estimates by Technology Field," RAND Journal of Economics, Vol. 29, 77-107. 
Schankerman, M. and A. Pakes [1986], "Estimates of the Value of Patent Rights in European Countries During the Post-1950 Period," Economic Journal, vol. 96, no. 384, 1052-1077.

Scharchburg, R.P. [1993], Carriages Without Horses: J. Frank Duryea and the Birth of the American Automobile Industry, Society of Automotive Engineers, Inc.

Scherer, F. M. [1965], "Innovation and Invention in the WattBoulton Steam Engine Venture", Technology and Culture 6, 165-187.

Scherer, F. M. [1984], Innovation and Growth: Schumpeterian Perspective, MIT Press.

Scherer, F.M. [2002], "The Economics of Human Gene Patents," Academic Medicine 77.

Scherer, F.M. [2003], "Global Welfare in Pharmaceutical Patenting", mimeo Haverford College, December. Forthcoming in The World Economy.

Scherer, F.M. [2004], Quarter Notes and Bank Notes. The Economics of Music Composition in the Eighteenth and Nineteenth Centuries. Princeton University Press.

Scherer F.M. and S. Weisbrod [1995], "Economic Effects of Strengthening Pharmaceutical Patent Protection in Italy", International Review of Industrial Property and Copyright Law 26, 1009-1024.

Schumpeter, J. [1911], The Theory of Economic Development, (translated into English in 1934), McGraw Hill.

Scotchmer, S. [1991], "Standing on the Shoulders of Giants: Cumulative Research and the Patent Law", Journal of Economic Perspectives 5, 29-41.

Scotchmer, S. [1999], "On the Optimality of the Patent Renewal System," RAND Journal of Economics, Vol. 30, 181-196.

Scotchmer, S. [2004], Innovation and Incentives, MIT Press.

Selgin, G. and J. Turner [2006], "James Watt as an Intellectual Monopolist. Comment on Boldrin and Levine", International Economic Review 47, 1341-1354.

Sokoloff, K. L. and Z. Kahn [2000]: "Intellectual Property Institutions in the United States: Early Development and Comparative Perspective," UCLA. 